\title{
Frequencies of 23 functionally significant variant alleles related with metabolism of antineoplastic drugs in the Chilean population: comparison with Caucasian and Asian populations
}

\section{Ángela Roco ${ }^{1,2,3}$, Luis Quiñones ${ }^{1}$ *, José A. G. Agúndez ${ }^{4}$, Elena García-Martín ${ }^{5}$, Valentina Squicciarini ${ }^{1}$, Carla Miranda ${ }^{1}$, Joselyn Garay ${ }^{1}$, Nancy Farfán ${ }^{1}$, Iván Saavedra ${ }^{1}$, Dante Cáceres ${ }^{1,6}$, Carol Ibarra ${ }^{1,7}$ and Nelson Varela ${ }^{1,8}$}

' Center of Pharmacological and Toxicological Research (IFT), Molecular and Clinical Pharmacology Program, Instituto de Ciencias Biomédicas, Faculty of Medicine, University of Chile, Santiago, Chile

2 School of Pharmacy, Faculty of Medicine, Andrés Bello University, Santiago, Chile

${ }^{3}$ San Juan de Dios Hospital, Santiago, Chile

${ }^{4}$ Department of Pharmacology, University of Extremadura, Cáceres, Spain

${ }^{5}$ Department of Biochemistry, University of Extremadura, Cáceres, Spain

${ }^{6}$ School of Public Health, Faculty of Medicine, University of Chile, Santiago, Chile

7 Santo Tomás University, Santiago, Chile

${ }^{8}$ School of Medical Technology, University of Chile, Santiago, Chile

\section{Edited by:}

Kathrin Klein, Dr. Margarete

Fischer-Bosch-Institute of Clinical

Pharmacology, Germany

\section{Reviewed by:}

Guilherme Suarez-Kurtz, Instituto

Nacional de Cancer, Brazil

M. Isabel Lucena, Universidad de Malaga, Spain

\section{*Correspondence:}

Luis Quiñones, Laboratory of

Chemical Carcinogenesis and

Pharmacogenetics IFT, Molecular and

Clinical Pharmacology Program,

ICBM, Faculty of Medicine, University

of Chile, Santiago, Chile.

e-mail: lquinone@med.uchile.cl

Cancer is a leading cause of death worldwide. The cancer incidence rate in Chile is $133.7 / 100,000$ inhabitants and it is the second cause of death, after cardiovascular diseases. Most of the antineoplastic drugs are metabolized to be detoxified, and some of them to be activated. Genetic polymorphisms of drug-metabolizing enzymes can induce deep changes in enzyme activity, leading to individual variability in drug efficacy and/or toxicity. The present research describes the presence of genetic polymorphisms in the Chilean population, which might be useful in public health programs for personalized treatment of cancer, and compares these frequencies with those reported for Asian and Caucasian populations, as a contribution to the evaluation of ethnic differences in the response to chemotherapy. We analyzed 23 polymorphisms in a group of 253 unrelated Chilean volunteers from the general population. The results showed that $C Y P 2 A 6^{*} 2, C Y P 2 A 6^{*} 3$, CYP2D6*3, CYP2C19*3, and CYP3A4*17 variant alleles are virtually absent in Chileans. CYP1A1*2A allele frequency (0.37) is similar to that of Caucasians and higher than that reported for Japanese people. Allele frequencies for CYP3A5*3(0.76) and CYP2C9*3(0.04) are similar to those observed in Japanese people. CYP1A1*2C(0.32), CYP1A2*1F(0.77), CYP3A4*1B(0.06), CYP2D6*2(0.41), and MTHFRT(0.52) allele frequencies are higher than the observed either in Caucasian or in Japanese populations. Conversely, CYP2C19*2 allelic frequency (0.12), and genotype frequencies for GSTT1 null (0.11) and GSTM1 null (0.36) are lower than those observed in both populations. Finally, allele frequencies for CYP2A6*4(0.04), CYP2C8*3(0.06), CYP2C9*2(0.06), CYP2D6*4(0.12), CYP2E1*5B(0.14), CYP2E 1*6(0.19), and UGT2B7*2(0.40) are intermediate in relation to those described in Caucasian and in Japanese populations, as expected according to the ethnic origin of the Chilean population. In conclusion, our findings support the idea that ethnic variability must be considered in the pharmacogenomic assessment of cancer pharmacotherapy, especially in mixed populations and for drugs with a narrow safety range.

Keywords: polymorphisms, biomarkers, CYP450, MTHFR, antineoplastic, biotransformation, pharmacogenetics, pharmacogenomics

\section{INTRODUCTION}

Cancer is a leading cause of death worldwide and the total number of cases globally is increasing. The number of cancer deaths is projected to increase $45 \%$ from 2007 to 2030 (from 7.9 million to 11.5 million deaths), influenced in part by an increasing and aging global population. The estimated rise takes into account expected slight declines in death rates for some cancers in high resource countries. New cases of cancer in the same period are estimated to increase from 11.3 million in 2007 to 15.5 million in 2030 (WHO, 2011). In Chile cancer have a rate of $133.7 \times 100,000$ inhabitants, is the second cause of death after cardiovascular diseases with a sustained increase in the time both, in the rates and in proportion of deaths. Chile has a number of 30,000 new cases and 36,000 hospitalizations per year. The first cause of cancer 
death in Chilean population is gastric cancer for both genders, with a rate of $19.8 \times 100,000$ inhabitants, followed by lung cancer $(15 \times 100,000$ inhabitants $)$, prostate $(10.4 \times 100,000$ inhabitants $)$, and gallbladder $(8.1 \times 100,000$ inhabitants; DEIS, 2011).

Though the principal achievements in the fight against cancer has been those related to preventive measures, the success in the treatment of an established cancer depends on the cancer stage when detected, on the type of cancer, and on its location. It is quite infrequent to find patients considered as "therapeutical success" because there is always a possibility that a tumor process may appear back (Arrastoa, 1998).

Chemotherapy for cancers has progressed from its introduction to clinical practice and constitutes the mainstay modality of therapy in these pathologies. Nevertheless, its use is limited by the inability to predict the response. In most cases the therapy choice is empirical. Nowadays there are more than 100 antineoplastic drugs, which are used either alone or combined. A combined therapy allows that drugs with different mechanism of action work together to destroy the larger possible amount of tumor cells, in order to reduce the possibility of resistance to a particular antineoplastic drug. The therapy to select, the dose, the method of administration and the frequency, and duration of the treatment, will depend on the type of cancer, its location, the rate of growth, how it is affecting the normal functions of the body, as well as on the patient's general health condition. Usually therapies can be managed by means of cycles that alternate drug administration with washout periods that allow healthy cells to recover from the effect of the medication.

The biotransformation of drugs, including antineoplastic agents, is done basically in two phases: phase I, catalyzed mainly by the cytochrome P450 system and phase II, by transferases that catalyze reactions of conjugation of xenobiotics with diverse molecules of endogenous nature as glucuronic acid, sulfates, acetate, glutathione, or some amino acids. The final outcome of both phases is to increase the hydrophilicity of chemicals facilitating the excretion through urine or bile (Rooney et al., 2004).

There is limited information available in human beings regarding the metabolism and pharmacokinetics interaction of antineoplastic drugs. Nevertheless, it is well known that clinical significant interactions exist between drugs that can render them less efficient if used simultaneously, and in some cases, produce unexpected effects.

The cytochrome P450 (CYP) system is the most important metabolic system responsible for the oxidation of numerous chemotherapeutic agents, and it is responsible to a great extent for the variability observed in response to drugs. For example, some enzymes of the CYP3A family play an important role in the metabolism of epidophilotoxin, ifosfamide, tamoxifen, taxol, and vinca alkaloids. Cytochrome P450 enzymes are also of great importance in the study of chemotherapy resistance. (Kivisto et al., 1995; Yao et al., 2000; Lin and Yu, 2001; García-Martín et al., 2006a; Quiñones et al., 2008).

Genetic polymorphisms of CYP enzymes can produce deep changes in enzyme activity, thus determining the individual response to a certain drug leading to poor, intermediate, extensive, or ultrarapid metabolizer phenotypes (Ingelman-Sundber, 2005; Jin, 2005). On the other hand, the glucuronidation of drugs is carried out by the UDP Glucuronyl transferases (UGT), which are also polymorphic in human beings, adding to the diversity of this reaction. In this respect, UGT2B7 has unique specificity for 3,4-catechol estrogens and estriol, suggesting that it may play an important role in regulating the level and activity of these potent estrogen metabolites. It is also able to conjugate major classes of drugs such as analgesics (morphine), carboxylic non-steroidal anti-inflammatory drugs (ketoprofen), anticarcinogens (all-trans retinoic acid), and tamoxifen. 802C/T mutation leads to UGT2B7 variants UGT2B7*1 (Y268) and UGT2B7*2 (H268) which has been suggested to increase the activity of the enzyme (Ritter et al., 1990; Coffman et al., 1997; Barre et al., 2007; Lazarus et al., 2009). Similarly, the human glutathione-S-transferases (GSTs), are polymorphic isoenzymes which show a wide subcellular distribution. GST alpha $(\alpha)$, kappa $(\kappa)$, mu $(\mu)$, pi $(\pi)$, omega $(\omega)$, sigma $(\sigma)$, theta $(\theta)$, and zeta ( $Z$ are being studied as possible genetic biomarkers of cancer and its chemotherapeutic treatment (Guengerich et al., 1992; Quiñones et al., 1999; Bredschneider et al., 2002). These enzymes are fundamental in the oxidative processes and detoxification of a wide variety of xenobiotics, including many chemotherapeutic drugs (Massad-Massade et al., 1997; Sargent et al., 1999; Clapper, 2000; Bredschneider et al., 2002; Petros et al., 2005). These polymorphisms have been postulated also as biomarkers for susceptibility to diverse types of cancer (IARC, 1999; Clapper, 2000; Au, 2001; Quiñones et al., 2001; Acevedo et al., 2003; Keshava et al., 2004; Lee et al., 2006; Cordero et al., 2010; Singh et al., 2011) showing marked interethnic differences (Stephens et al., 1994; Muñoz et al., 1998; Garte et al., 2001; Yasuda et al., 2008).

Another relevant enzyme is methylene tetrahydrofolate reductase (MTHFR) which converts 5,10-methylene tetrahydrofolate to 5 -methyl tetrahydrofolate. This reaction is required for the multistep process that converts the amino acid homocysteine to another amino acid, methionine. Polymorphisms of this enzyme predispose to serious bone marrow toxicity during treatment with agents that inhibit folate synthesis (e.g., methotrexate; Chiuslo et al., 2002; Yang et al., 2012).

Because of enzymes CYP1A1, CYP1A2, CYP2A6, CYP3A4/5, CYP2C8, CYP2C9, CYP2C19, CYP2E1, CYP2D6, GSTM1, GSTT1, UGT2B7, and MTHFR take part in the metabolism of oncological drugs (Table 1), the main goal of this study was to determine the allele frequencies of variants of these enzymes in a group representative of the Chilean population in order to describe genetic polymorphisms that might be useful in public health programs, and to compare these frequencies with other populations, as the first approximation to the evaluation of ethnic differences in the response to chemotherapies.

\section{MATERIALS AND METHODS STUDY POPULATION}

Blood samples were obtained from 253 unrelated volunteers living in Santiago of Chile (both sexes, 27-55 years old). The study group has a $37 \%$ Amerindian-Caucasian admixture, as determined by ABO blood group distribution (Valenzuela, 1988). The research was authorized by the Ethics Committee of the Faculty of Medicine of the University of Chile. All subjects signed an authorized 
informed consent. Table 1 shows general characteristics of the studied population.

\section{DNA EXTRACTION}

Extraction of genomic DNA was done by a standard procedure from whole blood using a commercial kit (High Pure PCR Template Preparation Kit, Roche Diagnostics ${ }^{\circledR}$ ) and DNA samples were stored at $-20^{\circ} \mathrm{C}$ until further analysis.

\section{GENOTYPING}

Genomic DNAs from peripheral blood were amplified by PCR using specific primers for detection of the specific allelic variants in study. For detection of polymorphisms $C Y P 1 A 1^{*} 2 A, C Y P 1 A 1^{*} 2 C$, CYP1A2*1F, CYP2E1*5B, CYP2E1*6, CYP2A6*2, CYP2A6*3, CYP2A6*4, CYP2D6*2, CYP2C9*2, CYP2C19*2, CYP3A4*1B, $C Y P 3 A 4^{*} 17, C Y P 3 A 5^{*} 3$, and $U G T 2 B 7^{*}$, amplicons were surrendered to digestion with the appropriate restriction enzyme to be analyzed through electrophoresis, in agarose gel $(2 \%)$ or polyacrylamide gel (16\%) according to methods previously reported (Hayashi et al., 1999; Kitagawa et al., 1999; Quiñones et al., 1999; Cavalli et al., 2001; LEE et al., 2005; Lin et al., 2005). CYP2D6*3 and CYP2D6* 4 were analyzed by means of allelespecific PCR (Heim and Meyer, 1990; Amrithraj et al., 2006). CYP2C9*3, CYP2C19*3, and CYP2C8*3 polymorphisms were analyzed with Taqman probes in an ABI 7500 Real Time PCR system, using specific probes previously described (Agúndez et al., 2009). Deletions of GSTM1 and GSTT1 were analyzed through PCR using $\beta$-globin gene as control (Quiñones et al., 1999; Rebbeck et al., 1999). Heterozygous and homozygous non-null individuals could not be differentiated, therefore double null genotypes $(-/-)$ are the null genotypes reported. Finally, to detect MTHFR C677T polymorphism we use a commercial Real Time kit (Roche Diagnostics $\left.{ }^{\circledR}\right)$.

\section{RESULTS AND DISCUSSION}

Pharmacogenetic research is directed to identify genes or gene products associated with diseases and, especially, allelic variants in enzymes of biotransformation that alter the individual response to drugs. These variants can modify the magnitude of the pharmacological effect, the threshold of toxicity, the efficacy of the drug, side effects, and drug-drug interactions. In this respect, it is particularly important at the time, to define pharmacogenetic profiles of patients with cancer to determine suitable dosages, to improve

Table 1 | General characteristics of the studied population.

\begin{tabular}{llll}
\hline Sex & Women & Men & Total \\
\hline Number & 155 & 98 & 253 \\
Age (years) & $33.6 \pm 13.6$ & $28.7 \pm 10.8$ & $31.7 \pm 12.8$ \\
Weight $(\mathrm{kg})^{*}$ & $61.8 \pm 9.1$ & $74.9 \pm 10.1$ & $66.8 \pm 11.4$ \\
Height $(\mathrm{m})^{*}$ & $1.60 \pm 0.06$ & $1.73 \pm 0.07$ & $1.65 \pm 0.09$ \\
BMI $\left(\mathrm{Kgm}^{-2}\right)^{*}$ & $24.1 \pm 3.3$ & $25.0 \pm 2.9$ & $24.5 \pm 3.2$ \\
A $_{\mathrm{A}-\mathrm{C}}: 37 \%{ }^{*}$ & & & \\
\end{tabular}

*Information is expressed as averages \pm SD; BMI: body mass index.

${ }^{* *}$ Amerindian-Caucasian Admixture (\%). efficacy, to avoid adverse reactions of the traditionally used drugs, and to develop new drugs according to the genetic-metabolic profile of the patients (Wilkinson, 2000). Moreover, ethnicity plays an important role in pharmacokinetics and pharmacodynamics of drugs (Ling and Lee, 2011; Kurose et al., 2012) giving rise a more complex situation in "mestizo" populations as South American people. In this sense, Chilean population is a genetic admixture originated primarily between Caucasian (mainly Spaniards) and native-American (mainly Mapuches) from a first single migration of Asians from Siberia 15,000 years ago through Beringia (Reich et al., 2012) and secondly from immigration, mostly from Germany, Croatia, France and Italy. This is a restriction to extrapolate the dosage of drugs with clinical studies performed in other ethnic groups. Another restriction is the poor information about the biotransformation enzyme polymorphisms in Chilean population. According to this, we have studied genetic polymorphisms of several enzymes, in a sub-group of the Chilean population, which metabolize mainly antineoplastic drugs used for chemotherapy in health institutions of Chile (Table 1). General characteristics of the analyzed population are shown in Table 2 . The mean age identifies a young adult population which has, in average, a normal mean weight, height, and body mass index and are a representative sample of the middle class Chilean population, which is supported by the Amerindian-Caucasian admixture (37\%).

The allele and genotype frequencies for metabolic enzymes included in this research are shown in the Table 3. Due to DNA shortage, not all DNA samples were analyzed for all polymorphisms. In Table 4 we compare allele frequencies found in this study in relation to Caucasian and Asian populations.

Our results show the absence of variant alleles $C Y P 2 A 6^{*} 3$, CYP2C19*3, and CYP3A4*17 such as it was also observed for Caucasians. In Japanese people CYP2A6*3 and CYP3A4* 17 are also absent, but the $C Y P 2 C 19^{*} 3$ allele has a frequency of 0.11 . $C Y P 1 A 1^{*} 2 A$ and $C Y P 2 A 6^{*} 2$ allele frequencies are similar to Caucasians but higher than the reported for Japanese people. CYP3A5*3 and CYP2C9*3 frequencies are similar to those in Japanese people, but different to the Caucasian people. $C Y P 1 A 1^{*} 2 C, C Y P 1 A 2^{*} 1 F, C Y P 3 A 4^{*} 1 B$, and $C Y P 2 D 6^{*} 2$ allelic frequencies are higher than those observed either in Caucasian or Japanese populations. MTHFRT allele frequency is higher than the observed in Caucasian and Japanese population, but also than the frequency reported previously by Nitsche et al. (2003) in other group of the Chilean population. We suggest that this difference could be explained by different genetic composition of the previously studied group, which could be more similar to Caucasians. Unfortunately, Nitsche et al. no reported the AmerindianCaucasian admixture percentage to evaluate this point.

On the other hand, CYP2C19*2, GSTT1 null and GSTM1 null frequencies are lower than those reported in Caucasian or Japanese population. Finally for $C Y P 2 C 8^{*} 3, C Y P 2 C 9^{*} 2$ and $* 3, C Y P 2 D 6^{*} 3$, $C Y P 2 D 6^{*} 4, C Y P 2 E 1^{*} 5 B$ and * 6 , as well as for UGT2B7*2 the frequencies described for Chileans are intermediate in relation to those described for Caucasian and Japanese population (SullivanKlose et al., 1996; Nasu et al., 1997; Chen et al., 1998, 1999; Chida et al., 1999; Paris et al., 1999; Sachse et al., 1999; Bhasker et al., 2000; Matsuo et al., 2001; Murata et al., 2001; Roy et al., 2005; Skarke et al., 2005; Nakajima et al., 2006; Krishnakumar 
Table 2 | Some antineoplastic drugs, substrates of polymorphic enzymes analyzed in this research (http://www. pharmacologyweekly.com/content/pages/cytochrome-cyp-p450enzyme-medication-herbs-substrates; Quiñones et al., 2008).

\begin{tabular}{|c|c|c|}
\hline Drugs & Enzyme & Cancer \\
\hline Cisplatin & GSTM, GSTT & Breast \\
\hline Cyclophosphamide & $\begin{array}{l}\text { CYP2B6, CYP2C19, } \\
\text { CYP3A4 }\end{array}$ & Leukemia, lymphoma \\
\hline Dacarbazine & $\begin{array}{l}\text { CYP1A1, CYP1A2, } \\
\text { CYP2E1 }\end{array}$ & $\begin{array}{l}\text { Melanoma, sarcoma, } \\
\text { lymphoma }\end{array}$ \\
\hline Docetaxel & $\begin{array}{l}\text { CYP2C8, CYP3A, } \\
\text { CYP1B1 }\end{array}$ & Breast, lung, stomach \\
\hline Doxorubicin & CYP3A4 & Sarcoma \\
\hline Ellipticine & CYP3A4, CYP1A & $\begin{array}{l}\text { Leukemia, myeloma, } \\
\text { lymphosarcoma }\end{array}$ \\
\hline Etoposide & $\begin{array}{l}\text { CYP3A4, CYP2E1, } \\
\text { CYP1A2 }\end{array}$ & $\begin{array}{l}\text { Testicle, lung, breast, } \\
\text { leukemia, lymphoma }\end{array}$ \\
\hline Ifosfamide & CYP2B6, CYP3A4 & Sarcoma, testicle \\
\hline Imatinib & CYP3A4, CYP3А5 & Leukemia \\
\hline Irinotecan & $\begin{array}{l}\text { CYP3A4/5 } \\
\text { UGT1A1 }\end{array}$ & Colon and rectum \\
\hline Methotrexate & MTHFR & Leukemia \\
\hline Mitoxantrone & CYP3A4, CYP1B1 & Leukemia, lymphoma \\
\hline Paclitaxel & CYP2C8, CYP3A4 & Breast, lung, ovary \\
\hline $\begin{array}{l}\text { Phortress } \\
\text { (2-(4-aminophenyl)- } \\
\text { benzotiazol) }\end{array}$ & CYP1A1, CYP1B1 & Ovary, breast \\
\hline Procarbazine & CYP1A1, CYP2B6 & $\begin{array}{l}\text { Lymphoma, brain, lung, } \\
\text { melanoma, testicle }\end{array}$ \\
\hline Tamoxifen & $\begin{array}{l}\text { CYP3A4, CYP2D6, } \\
\text { CYP2C9, CYP2C19, } \\
\text { CYP1B1, UGT2B7 }\end{array}$ & Breast \\
\hline Tegafur & $\begin{array}{l}\text { CYP2A6, CYP2C8, } \\
\text { CYP1A2 }\end{array}$ & Colon, rectum, stomach \\
\hline Teniposide & CYP2C19, CYP3A4/5 & $\begin{array}{l}\text { Leukemia, lung, brain, } \\
\text { bladder, myeloma }\end{array}$ \\
\hline Thiotepa & CYP2B6, CYP3A4 & Bladder \\
\hline Topotecan & CYP3A4/5 & Ovary, lung \\
\hline Vinblastine & CYP3A4/5 & Lymphoma, osteosarcoma \\
\hline Vincristine & CYP3A4/5 & Lymphoma \\
\hline Vindesine & CYP3A4/5 & Lung \\
\hline Vinrelbine & CYP3A4/5 & Lung \\
\hline
\end{tabular}

et al., 2012; Kurose et al., 2012), which is expected because Chilean population is considered a mixed ethnicity between both races.

Some limitations in this study should be pointed out. Only some polymorphism of the many (>80) CYP2D6 known were genotyped. We select only CYP2D6 polymorphisms that have shown better reported relationship with plasma levels of antineoplastic drugs and those that have higher allele frequencies, based on a previous pilot study in Chilean subjects (Dr. Monica Acuña, Personal Communication). Similarly, same criteria were used for choosing the other studied polymorphisms, based on both literature and our own previous research. Nevertheless, some potentially relevant CYP variants are currently under investigation in our laboratory (CYP2D6*2xN, CYP2D6*5, CYP2D6*10, CYP2C8*3, and $\left.\mathrm{CYP} 2 \mathrm{C} 8^{*} 4\right)$, to complement the results shown in this paper.

Additionally, we have no data for other relevant polymorphic enzymes, such as for example, CYP1B1 and CYP2B6, responsible for the metabolism of several antineoplastic drugs (Quiñones et al., 2008) and UDP Glucuronyl transferase 1A1, involved in metabolism of irinotecan (Dias et al., 2012). We did not analyze thiopurine $S$-methyltransferase (TPMT), a cytosolic phase II enzyme involved in the metabolism of azathioprine, thiopurine, and thioguanine (Zhou, 2006). However the frequency of four allelic variants of this gene $\left({ }^{*} 2,{ }^{*} 3 \mathrm{~A},{ }^{*} 3 \mathrm{~B}\right.$, and $\left.{ }^{*} 3 \mathrm{C}\right)$ were analyzed previously in Chilean population by Alvarez et al. (2009) showing that the presence of $* 3 \mathrm{~A}$ allele is the most prevalent, which is similar to Caucasians, giving a first approach to the use of this polymorphism in clinical practice in Chilean patients.

Another limitation of the present research is the use of Japanese population as proxy of the ancestral Asians of Chilean people. We use this population as reference due to two main facts: (a) there is very good and complete information about these polymorphisms in Japanese people and (b) recently, have been reported no great differences among Japanese and other Asian populations, particularly with respect to Chinese population (Kurose et al., 2012).

On the other hand, drug-drug pharmacological interactions, some epigenetic and environmental factors, and alternative metabolic routes should not be excluded to describe response to antineoplastic agents, which is per se a multifactorial event. Thus, the research in this area must identify these factors and potential gene - environment interactions that modulate response to these drugs.

Some polymorphisms have been studied in other South American countries (Isaza et al., 2000; Gaspar et al., 2002; Fernández et al., 2004; Gattas et al., 2004; Vianna-Jorge et al., 2004; Almeida et al., 2005; Lizcano Fernández, 2005; Rossini et al., 2006; Schlawicke et al., 2007; Canalle et al., 2008; Rodríguez et al., 2008; Castaño-Molina et al., 2009; Dorado et al., 2011), but the comparison with Chilean Mestizo population is very difficult because of the divergent origin of these populations. Chilean population is different from other South American countries, from Brazilian people for example, which have African and Portuguese contribution with great pharmacogenomic diversity, or from Argentina and Uruguay populations, which are multiethnic countries, with Amerindian-European admixture, but mostly with Italians (Lizcano Fernández, 2005). In this respect, in South America, the region one of the most diverse genetic background in the world, four main components have contributed to the present-day population: Amerindians (pre-Columbian inhabitants); Iberians (conquerors) who dominated the continent until the nineteenth century, Africans (imported as slaves by the colonizers); and postindependence immigrants from overseas (mostly Italy and Germany but also from France, South Asia, and Japan). Therefore, we suggest that studies of these pharmacogenes in Chileans should be used to develop pharmacogenetic tools for this specific population, rather than extrapolating results obtained to other populations. 


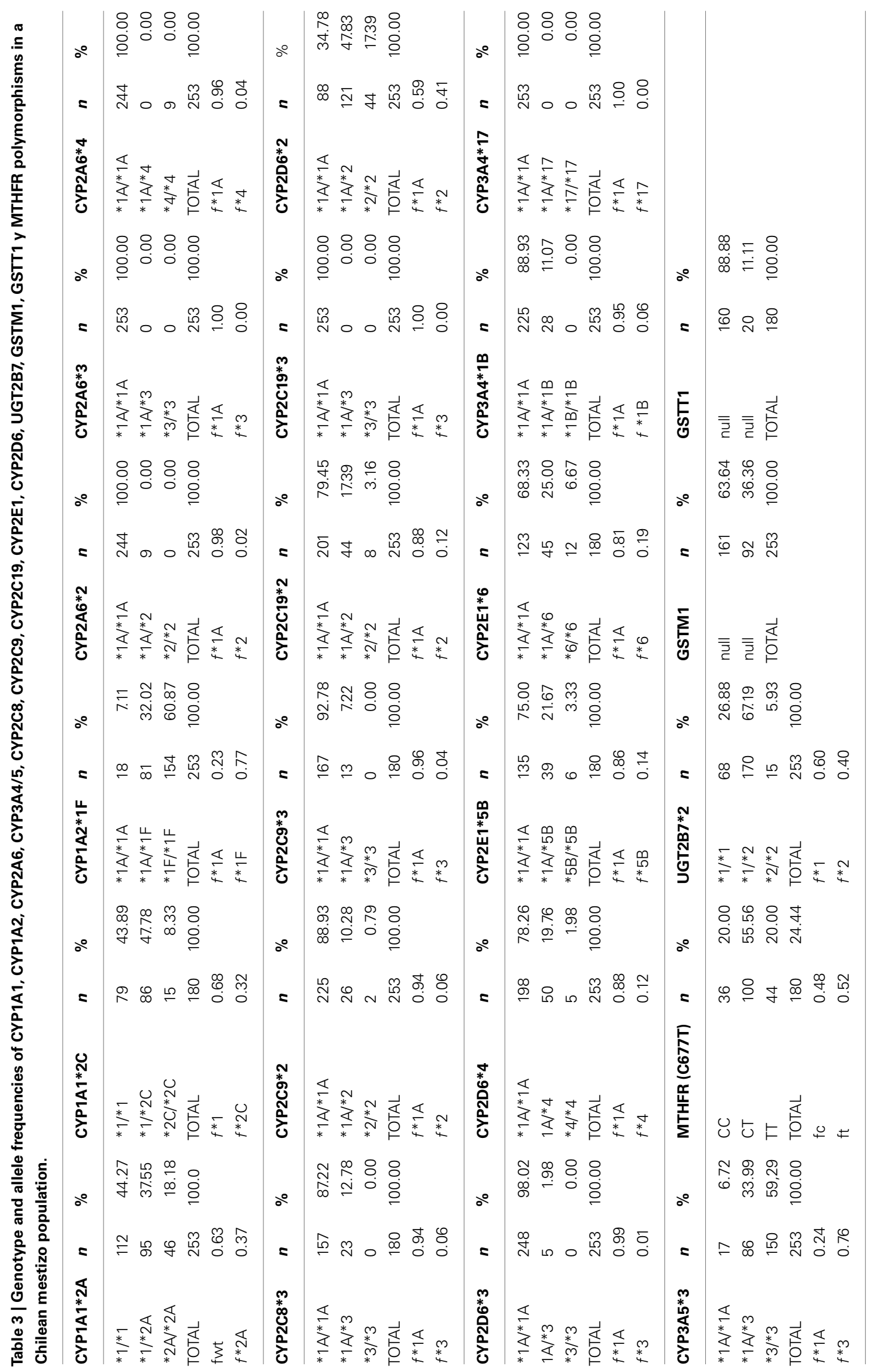


Table 4 | Comparison of allelic frequencies of CYP1A1, CYP1A2, CYP2A6, CYP3A4, CYP3A5, CYP2C8, CYP2C9, CYP2C19, CYP2D6, CYP2E1, GSTM1, GSTT1, UGT2B7, and MTHFR in Caucasian, Japanese, and Chilean populations.

Alle Frequencies

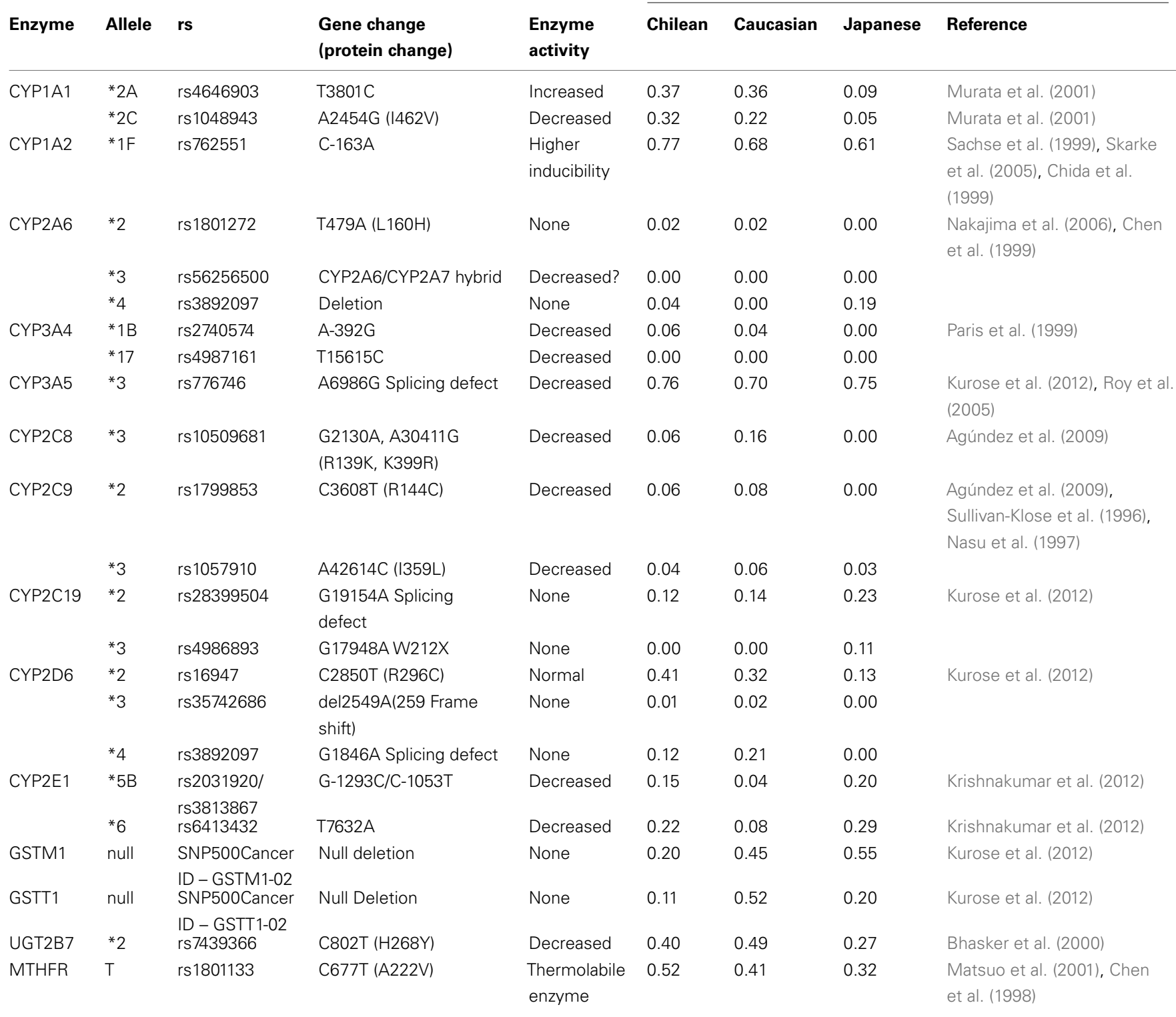

The frequencies observed in metabolic polymorphism studied in Chilean population were distinct from paternal races. These results contribute to better understanding of the basis of ethnic variation in drug metabolism and response (Agúndez, 2004; García-Martín et al., 2006b; Yasuda et al., 2008), and suggest a complex genetic profile of this "mestizo" population, which should be considered in pharmacotherapy, especially for drugs with a narrow safety range, particularly in cancer chemotherapy (García-Martín, 2008; Quiñones et al., 2008). These established genotype frequencies may be used for studying the phenotype variation in further studies. Thus, it may be a good contribution for further studies on the clinical application of pharmacogenomics in Asian-Caucasian mixed races.

\section{CONCLUSION}

Profound variation in polymorphisms of metabolizing enzymes have been described in diverse populations, including enzymes that take part in the metabolism of chemotherapeutics drugs (50). In this sense, our results agree with these observations when we compare the analyzed sub-group with Asian and Caucasian populations (Table 4).

As Chilean population represents a mixed ethnicity mainly between native-Americans and Caucasians (mostly Spaniards) the data obtained might help to understand inter ethnic differences not only for single polymorphisms, but also the function of simultaneous polymorphisms in metabolic genes in each subject, to explain differences in response to chemotherapy. 
This investigation contributes to have a first pattern of several relevant polymorphisms in metabolizing enzymes (CYP1A1, CYP1A2, CYP2A6, CYP2C8, CYP2C9, CYP2C19, CYP2D6, CYP2E1, CYP3A4/5, GSTM1, GSTT1, UGT2B7, and MTHFR) in Chilean people, which can give course for a genetic - population investigation of these polymorphisms helping to the understanding of susceptibility to drugs and pathologies in this population, which already has been suggested by our group of research for some specific genes (Quiñones et al., 1999, 2001, 2008; Acevedo et al., 2003; Lee et al., 2006; Cordero et al., 2010).

The knowledge of genetic variants involved in the metabolism of the antineoplastic drugs in the Chilean population will help to the prediction of their clinical efficacy and/or toxicity, and therefore, will help us to the design personalized cancer treatments to improve therapeutic response and diminish the adverse effects improving cost-efficacy of treatments.

Finally, based on scientific literature and our experience, we believe that, at least in Chilean population, MTHFR/methotrexate, GST/cisplatin, and CYP2D6/tamoxifen are the potential more

\section{REFERENCES}

Acevedo, C., Opazo, J. L., Huidobro, C., Cabezas, J., Iturrieta, J., and Quiñones, L. (2003). Positive correlation between single or combined genotypes of CYP1A1 and GSTM1 in relation to prostate cancer in Chilean people. Prostate 57, 111-117.

Agúndez, J. A. (2004). Cytochrome P450 gene polymorphism and cancer. Curr. Drug Metab. 5, 211-224.

Agúndez, J. A., García-Martín, E., and Martínez, C. (2009). Genetically based impairment in CYP2C8- and CYP2C9-dependent NSAID metabolism as a risk factor for gastrointestinal bleeding: is a combination of pharmacogenomics and metabolomics required to improve personalized medicine? Expert Opin. Drug Metab. Toxicol. 5,607-620.

Almeida, S., Zandona, M. R., Franken, N., Callegari-Jacques, S. M., OsorioWender, M. C., and Hutz, M. H. (2005). Estrogen-metabolizing gene polymorphisms and lipid levels in women with different hormonal status. Pharmacogenomics J. 5, 346-351.

Alvarez, L. L., Venegas, S. M., Larrondo, L. M., Becerra, B. N., Castro, L. A., and Quera, P. R. (2009). Thiopurine S-methyltransferase gene polymorphism in Chilean blood donors. Rev. Med. Chil. 137, 185-192.

Amrithraj, N., Chandrasekaran, A., Sam, S. A., Gerard, N., and Rajagopal, K. (2006). CYP2D6 genetic polymorphism in South Indian population. Biol. Pharm. Bull. 29, 1655-1658.

Arrastoa, J. (1998). Cáncer Diagnóstico y Tratamiento. Santiago: Ed. Mediterráneo.
Au, W. W. (2001). Life style factors and acquired susceptibility to environmental disease. Int. J. Hyg. Environ. Health 204, 17-22.

Barre, L., Fournel-Gigleux, S., Finel, M., Netter, P., Magdalou, J., and Ouzzine, M. (2007). Substrate specificity of the human UDPglucuronosyltransferase UGT2B4 and UGT2B7. Identification of a critical aromatic amino acid residue at position 33. FEBS J. 274, 1256-1264.

Bhasker, C. R., McKinnon, W., Stone, A., Lo, A. C., Kubota, T., Ishizaki, T., et al. (2000). Genetic polymorphism of UDP-glucuronosyl transferase 2B7 (UGT2B7) at amino acid 268: ethnic diversity of alleles and potential clinical significance. Pharmacogenetics 10, 679-685.

Bredschneider, M., Klein, K., Murdter, T. E., Marx, C., Eichelbaum, M., Nussler, A. K., et al. (2002). Genetic polymorphisms of glutathione S-transferase A1, the major glutathione S-transferase in human liver: consequences for enzyme expression and busulfan conjugation. Clin. Pharmacol. Ther. 71, 479-487.

Canalle, R., Andrade, V., Queiroz, R., Scrideli, C., Lopes, L., and Tone, L. (2008). Influencia dos polimorfismos no gene de biometabolismo CYP3A5 na susceptibilidade a leukemia linfoblastica aguda da infancia e na resposta ao tratamiento. Congresso Brasileiro de Genética 54, 11.

Castaño-Molina, E., Santacoloma, M., Arango, L., and Camargo, M. (2009). CYP1A1, CYP2E1 y riesgo a cáncer gástrico en una población colombiana de alta incidencia. Acta Biol.

relevant gene/drug pairs which are closer for monitoring use in clinical practice.

\section{AUTHORS' CONTRIBUTIONS}

Angela Roco: AB, ES; Luis Quiñones: AB, ES, FG; José AG. Agúndez: FG; Elena García-Martín: FG; Valentina Squicciarini: AB; Carla Miranda: AB; Joselyn Garay: AB; Nancy Farfán: AB; Dante Cáceres: ES; Carol Ibarra: AB; Nelson Varela: AB; Iván Saavedra: FG.

\section{ACKNOWLEDGMENTS}

Work at author's laboratories have been financed partly with Grants from Health Fogarty International Center; DI REIN/05, University of Chile; Sociedad Chilena de Ororrinolaringología Grant; Chilean Fondecyt grant n³020043; FIS PS09/00943, PS09/00469, and RETICS RD07/0064/0016 from Fondo de Investigación Sanitaria Instituto de Salud Carlos III, Spain; GR10068 from Junta de Extremadura, Spain and FEDER funds from the European Union.

Colomb. 14, 203-216.

Cavalli, S., Hirata, M., and Hirata, R. (2001). Detection of MboII polymorphism at $5^{\prime}$ promoter region of Cyp3A4. Clin. Chem. 47, 348-351.

Chen, G. F., Tang, Y. M., Green, B. Lin, D. X., Guengerich, F. P., Daly, A. K., et al. (1999). Low frequency of CYP2A6 gene polymorphism as revealed by a one-step polymerase chain reaction method. Pharmacogenetics 9, 327-332.

Chen, J., Giovanunucci, E., and Hankinson, S. E. (1998). A prospective study of methylene tetrahydrofolate reductase and methionine synthase gene polymorphisms, and risk of colorectal adenoma. Carcinogenesis 19, 2129-2132.

Chida, M., Yokoi, T., Fukui, T., Kinoshita, M., Yokota, J., and Kamataki, T. (1999). Detection of three genetic polymorphisms in the $5^{\prime}$-flanking region and intron 1 of human CYP1A2 in the Japanese population. Jpn. J. Cancer Res. 90, 899-902.

Chiuslo, P., Reddiconto, G., Casorelli, I., Laurentil, L., Sora, F., Mele, L., et al. (2002). Preponderance of methylene tetrahydrofolate reductase C677T homozygosity among leukemia patients intolerant to methotrexate. Ann. Oncol. 13, 1915-1918.

Clapper, M. L. (2000). Genetic polymorphism and cancer risk. Curr. Oncol. Rep. 2, 251-256.

Coffman, B., Rios, G., King, C., and Tephly, T. (1997). Human UGT2B7 catalyzes morphine glucuronidation. Drug Metab. Dispos. 25, 1-4.

Cordero, K., Espinoza, I., Cáceres, D., Roco, A., Miranda, C., Squicciarini, V., et al. (2010). Oral cancer susceptibility associated with
CYP1A1 and GSTM1 genotypes in Chilean people. Oncol. Lett. 1, 549-554.

DEIS, MINSAL. (2011). Available at: http://deis.minsal.cl/vitales/ defunciones_serie/Defunciones_ Mortalidad_Tumores_Malignos_ 2000-2009.htm [accessed June 20, 2012].

Dias, M. M., McKinnon, R. A., and Sorich, M. J. (2012). Impact of the $\mathrm{UGT}_{1 \mathrm{~A} 1}{ }^{*} 28$ allele on response to irinotecan: a systematic review and meta-analysis. Pharmacogenomics 13, 889-899.

Dorado, P., Sosa, M. G., Peñas-Lledó, E., Alanis-Bañuelos, R. E., Wong, M. L., Linicio, J., et al. (2011). Cyp2C9 allele frequency differences between populations of mexican mestizo, mexican tepehuanco, and spanairds. Pharmacogenomics J. 11, 108-112.

Fernández, T., García, S. I., Steppar, N., and Pirola, C. J. (2004). Asociación entre genotipo de CYP3A5 y la obesidad de una población argentina adolescente. Medicina (Mex.) 64(Suppl. II), 84.

García-Martín, E. (2008). Interethnic and intraethnic variability of NAT2 single nucleotide polymorphisms. Curr. Drug Metab. 9, 487-497.

García-Martín, E., Pizarro, R. M. Martínez, C., Gutierrez-Martín, Y., Pérez, G., Jover, R., et al. (2006a). Acquired resistance to the anticancer drug paclitaxel is associated with induction of cytochrome P450 2C8. Pharmacogenomics 7, 575-585.

García-Martín, E., Martínez, C., Ladero, J. M., and Agúndez, J. A. (2006b). Interethnic and intraethnic variability of CYP2C8 and CYP2C9 polymorphisms in healthy individuals. Mol. Diagn. Ther. 10, 29-40. 
Garte, S., Gaspari, L., and Alexandrie, A.-K. (2001). Metabolic gene polymorphisms frequencies in control populations. Cancer Epidemiol. Biomarkers Prev. 10, 1239-1249.

Gaspar, P. A., Kvitko, K., Papadopulos, L., Hutz, M., and Weimer, T. A. (2002). High frequency of CYP1A1*2C allele in Brazilian populations. Hum. Biol. 74, 235-242.

Gattas, G., Kato, M., Soares-Vieira, J. A., Siroque, M. S., Kohler, P., Gómez, L., et al. (2004). Ethnicity and glutathione S-transferase (GSTM1/GSTT1) polymorphisms in a Brazilian population. Braz. J. Med. Biol. Res. 37, 451-458.

Guengerich, F. P., Shimada, T., Raney, K. D., Yun, C. H., Meyer, D. J., Ketterer, B., et al. (1992). Elucidation of catalytic specificities of human cytochrome P450 and glutathione Stransferase enzymes and relevance to molecular epidemiology. Environ. Health Perspect. 98, 75-80.

Hayashi, S. I., Watanabe, J., and Kawajiri, K. (1999). Genetic polymorphism in the $5^{\prime}$-flanking region change the transcriptional regulation of the human cytochrome P450IIE1 gene. J. Biochem. 110, 559-565.

Heim, M., and Meyer, U. (1990). Genotyping of poor metabolizers of Japanese by allele-specific PCR amplification. Lancet 336, 529-532.

IARC. (1999). International Agency for Research on Cancer. Lyon, France.

Ingelman-Sundber, G. M. (2005). Genetic polymorphism of cytochrome P450 2D6: clinical consequences, evolutionary aspects and functional diversity. Pharmacogenomics J. 5, 6-13.

Isaza, C., Henao, J., López, A. M., and Cacabelos, R. (2000). Isolation, sequence and genotyping of the drug metabolizer CYP2D6 gene in the Colombian population. Methods Find Exp. Clin. Pharmacol. 22, 695-705.

Jin, Y. (2005). Cyp2D6 genotype, antidepressant use, and tamoxifen metabolism during adjuvant breast cancer treatment. J. Natl. Cancer Inst. 97, 30-39.

Keshava, C. H., McCanlies, E., and Weston, A. (2004). CYP3A4 polymorphims-potential risk factor for breast and prostate cancer: a HuGE review. Am. J. Epidemiol. 160, 825-841.

Kitagawa, K., Kunigita, N., Katoh, T., Yang, M., and Kawamoto, T. (1999). The significance of the homozygous CYP2A6 deletion on nicotine metabolism: a new genotyping method of CYP2A6 using a single
PCR-RFLP. Biochem. Biophys. Res. Commun. 262, 164-151.

Kivisto, K. T., Kroemer, H. K., and Eichelbaum, M. (1995). The role of human cytochrome P450 enzymes in the metabolism of anticancer agents: implications for drug interactions. Br. J. Clin. Pharmacol. 40, 523-530.

Krishnakumar, D., Gurusamy, U., Dhandapani, K., Surendiran, A., Baghel, R., Kukreti, R., et al. (2012). Genetic polymorphisms of drugmetabolizing phase I enzymes CYP2E1, CYP2A6, and CYP3A5 in South Indian population. Fundam. Clin. Pharmacol. 26, 295-306.

Kurose, K., Sugiyama, E., and Saito, Y. (2012). Population differences in major functional polymorphisms of pharmacokinetic/pharmacodynamicsrelated genes in Eastern Asians and Europeans: implications in the clinical trials for novel drug development. Drug Metab. Pharmacokinet. 27, 9-54.

Lazarus, P., Blevins-Primeau, A. S., Zheng, Y., and Suna, D. (2009). Potential role of UGT pharmacogenetics in cancer treatment and prevention: focus on tamoxifen. Ann. N. Y. Acad. Sci. 1155, 99-111.

Lee, K., Cáceres, D., Varela, N., Csendes, A., Ríos, H., and Quiñones, L. (2006). Evaluation of CYP1A1 and GSTM1 as gastric cancer susceptibility biomarkers: influence of smoking habit and alcohol consumption. Rev. Med. Chil. 134, 1107-1115.

LEE, S., Bell, D., Coulter, J., Ghanayem, B., and Goldstein, J. (2005). Recombinant CYP3A4*17 is defective in metabolizing the hypertensive drug nifedipine, and the CYP3A4*17 allele may occur on the same chromosome as CYP $3 \mathrm{~A} 5 * 3$, representing a new putative defective CYP3A haplotype. J. Pharmacol. Exp. Ther. 313, 302-309.

Lin, G. F., Guo, W. C., Chen, J. G., Qin, Y. Q., Golka, K., Xiang, C. Q., et al. (2005). An association of UDPglucuronosyltransferase 2B7 C802T (His268Tyr) polymorphism with bladder cancer in benzidine-exposed workers in China. Toxicol. Sci. 85, 502-506.

Lin, J., and Yu, A. (2001). Interindividual variability in inhibition and induction of cytochrome P450 enzymes. Annu. Rev. Pharmacol. Toxicol. 41, 535-567.

Ling, W. H., and Lee, S. C. (2011). Interethnic differences - how important is it in cancer treatment? Ann. Acad. Med. Singap. 40, 356-361.

Lizcano Fernández, F. (2005). Composición Étnica de las Tres Áreas
Culturales del Continente Americano a Comienzo del Siglo XXI (in Spanish) Convergencia, Vol. 38 (Mexico: Universidad Autónoma del Estado de México), 185-232.

Massad-Massade, L., Ribrag, V., Marie, J. P., Faussat, A. M., Bayle, C., Dreyfus, F., et al. (1997). Glutathione system, topoisomerase II level and multidrug resistance phenotype in acute myelogenous leukemia before treatment and at relapse. Anticancer Res. 17, 4647-4651.

Matsuo, K., Susuki, R., and Hamajina, N. (2001). Association between polymorphisms of folate and methionine metabolizing enzyme and susceptibility to malign lymphoma. Blood 97, 3205-3209.

Muñoz, S., Vollrath, V., Vallejos, M. P., Miquel, J. F., Covarrubias, C., Raddatz, A., et al. (1998). Genetic polymorphisms of CYP2D6 CYP1A1, and CYP2E1 in the SouthAmerindian population of Chile. Pharmacogenetics 8, 343-351.

Murata, M., Watanabe, M., and Yamanaka, M. (2001). Genetic polymorphisms in cytochrome P450 (CYP) 1A1, CYP1A2, CYP2E1, glutathione $\mathrm{S}$ transferase (GST) M1 and GSTT1 and susceptibility to prostate cancer in Japanese population. Cancer Lett. 165 , 171-177.

Nakajima, M., Fukami, T., Yamanaka, H., Higashi, E., Sakai, H., Yoshida, R., et al. (2006). Comprehensive evaluation of variability in nicotine metabolism and CYP2A6 polymorphic alleles in four ethnic populations. Clin. Pharmacol. Ther. 80, 282-297.

Nasu, K., Kubota, T., and Ishizaki, T. (1997). Genetic analysis of CYP2C9 polymorphisms in Japanese population. Pharmacogenetics 7, 405-409.

Nitsche, F., Alliende, M. A., Santos, J. L., Pérez, F., Santa María, L., Hertrampf, E., et al. (2003). Frequency of $\mathrm{C} 677 \mathrm{~T}$ polymorphism of 5, 10-methylenetetrahydrofolate reductase (MTHFR) in Chilean mothers of spina bifida cases and controls. Rev. Med. Chil. 131, 1399-1404.

Paris, P. L., Kupelian, P. A., Hall, J. M., Williams, T. L., Levin, H., Klein, E. A., et al. (1999). Association between a CYP3A4 genetic variant and clinical presentation in AfricanAmerican prostate cancer patients. Cancer Epidemiol. Biomarkers Prev. 8, 901-905.

Petros, W., Hopkins, P., Spruill, S., Broadwater, G., Vredenburgh, J. J., Colvin, O. M., et al. (2005). Association between drug metabolism genotype, chemotherapy pharmacokinetics, and overall survival in patients with breast cancer. J. Clin. Oncol. 23, 6117-6125.

Quiñones, L., Berthou, F., Varela, N., Simon, B., Gil, L., and Lucas, D. (1999). Ethnic susceptibility to cancer: differences in CYP2E1, CYP1A1 and GST $\mu$ genetic polymorphisms between French and Chilean populations. Cancer Lett. 141, 167-171.

Quiñones, L., Lucas, D., Godoy, J., Cáceres, D., Berthou, F., Varela, N., et al. (2001). CYP1A1, CYP2E1, and GSTM1 genetic polymorphisms. The effect of single and combined genotypes on lung cancer susceptibility in Chilean people. Cancer Lett. 174, 35-44.

Quiñones, L., Rosero, M., Roco, A., Moreno, I., Sasso, J., Varela, N., et al. (2008). Papel de las enzimas citocromo p450 en el metabolismo de fármacos antineoplásicos: situación actual y perspectivas terapéuticas. Rev. Med. Chil. 136, 1327-1335

Rebbeck, T. R., Walker, A. H., Jaffe, J. M., White, D. L., Wein, A. J., and Malkowicz, S. B. (1999). Glutathione S-transferase-mu (GSTM1) and theta (GSTT1) genotypes in the etiology of prostate cancer. Cancer Epidemiol. Biomarkers Prev. 8(4 Pt 1), 283-287.

Reich, D., Patterson, N., Campbell, D., Tandon, A., Mazieres, S., Ray, N., et al. (2012). Reconstructing native American population history. Nature 488, 370-374.

Ritter, J. K., Sheen, Y. Y., and Owens, I. S. (1990). Cloning and expression of human liver UDPglucuronosyltransferase in COS-1 cells. 3,4-Catechol estrogens and estriol as primary substrates. J. Biol. Chem. 265, 7900-7906.

Rodríguez, A., Groot, H., Varona, M., Narvaez, D., Ortíz, S., and Torres, C. (2008). Empleo de polimorfismos genéticos de las enzimas metaboló cias CYP2E1, GSTM1 y GSTT1 como biomarcadores de susceptibilidad en una población expuesta a disolventes orgánicos. Colomb. Med. 39, 15.

Rooney, P. H., Telfer, C., McFadyen, M. C., Melvin, W. T., and Murray, G. I. (2004). The role of cytochrome P450 in cytotoxic bioactivation: future therapeutic directions. Curr. Cancer Drug Targets 4, 257-265.

Rossini, A., Soares Lima, S., Rapozo, D., Faria, M., Albano, R. M., and Ribeiro Pinto, L. (2006). CYP2A6 and CYP2E1 polymorphisms in a Brazilian population living in Rio de 
Janeiro. Braz. J. Med. Biol. Res. 39, 195-201.

Roy, J. N., Lajoie, J., Zijenah, L., Barama, A., Poirier, C., Ward, B., et al. (2005). Short communication: CYP3A5 genetic polymorphisms in different ethnic populations. Drug Metab. Dispos. 33, 884-887.

Sachse, C., Brockmöller, J., Bauer, S., and Roots, I. (1999). Functional significance of a $\mathrm{C} \rightarrow \mathrm{A}$ polymorphism in intron 1 of the cytochrome P450 CYP1A2 gene tested with caffeine. Br. J. Clin. Pharmacol. 47, 445-449.

Sargent, J. M., Williamson, C., Hall, A. G., Elgie, A. W., and Taylor, C. G. (1999). Evidence for the involvement of the glutathione pathway in drug resistance in AML. Adv. Exp. Med. Biol. 457, 205-209.

Schlawicke, K., Broberg, K., Concha, G., Nermell, B., Warholm, M., and Vahter, M. (2007). Genetic polymorphisms influencing arsenic metabolism: evidence from Argentina. Environ. Health Perspect. 115, 599-605.

Singh, S., Kumar, V., Singh, P., Thakur, S., Benergee, B., Singh Rautele, R., et al. (2011). Genetic polymorphisms of GSTM1, GSTT1, and GSTP1 and susceptibility to DNA damage in workers occupationally exposed to organophosphate pesticides. Mutat. Res. 745, 36-42.

Skarke, C., Kirchhof, A., Geisslinger, G., and Lötsch, J. (2005). Rapid genotyping for relevant CYP1A2 alleles by pyrosequencing. Eur. J. Clin. Pharmacol. 61, 887-892.

Stephens, E. A., Taylor, J. A., Kaplan, N., Yang, C. H., Hsieh, L. L., Lucier, G. W., et al. (1994). Ethnic variation in the CYP2E1 gene: polymorphism analysis of 695 African-Americans, EuropeanAmericans and Taiwanese. Pharmacogenetics 4, 185-192.

Sullivan-Klose, T. H., Ghanayem, B., Bell, D. A., Zhang, Z. Y., Kamisky, L. S., Shenfield, G. M., et al. (1996). The role of CYP2C9-Leu 359 allelic variation in the tolbutamide polymorphisms. Pharmacogenetics 6, 341-349.

Valenzuela, C. Y. (1988). On sociogenetic clines. Ethol. Sociobiol. 9, 259-268.

Vianna-Jorge, R., Perini, J., Rondinelli, E., and Suarez-Kurtz, G. (2004). CYP2C9 genotypes and the pharmacokinetics of tenoxicam in Brazilian. Clin. Pharmacol. Ther. 76, 18-26.

WHO. (2011). Available at: http://www.who.int/features/ qa/15/es/index.html [accessed June 20, 2012].
Wilkinson, G. (2000). Drug metabolism and variability among patients in drug response. N. Engl. J. Med. 352, 2211-2221.

Yang, L., Hu, X., and Xu, L. (2012). Impact of methylenetetrahydrofolate reductase (MTHFR) polymorphisms on methotrexate-induced toxicities in acute lymphoblastic leukemia: a meta-analysis. Tumour Biol. 33, 1445-1454.

Yao, D., Ding, S., Burchell, B., Wolf, C. R., and Friedbergt, T. (2000). Detoxication of vinka alkaloids by human P450 CYP3A4-mediated metabolism: implications for the development of drug resistance. J. Pharmacol. Exp. Ther. 294, 387-395.

Yasuda, S. U., Zhang, L., and Huang, S.-M. (2008). The role of ethnicity in variability in response to drugs: focus on clinical pharmacology studies. Clin. Pharmacol. Ther. $84,417-423$.

Zhou, S. (2006). Clinical pharmacogenomics of thiopurine S-methyltransferase. Curr. Clin. Pharmacol. 1, 119-128.

Conflict of Interest Statement: The authors declare that the research was conducted in the absence of any commercial or financial relationships that could be construed as a potential conflict of interest.

Received: 29 August 2012; accepted: 10 October 2012; published online: 02 November 2012.

Citation: Roco Á, Quiñones L, Agúndez JAG, García-Martín E, Squicciarini V, Miranda C, Garay J, Farfán $N$, Saavedra I, Cáceres D, Ibarra C and Varela $N$ (2012) Frequencies of 23 functionally significant variant alleles related with metabolism of antineoplastic drugs in the Chilean population: comparison with Caucasian and Asian populations. Front. Gene. 3:229. doi: 10.3389/fgene. 2012.00229

This article was submitted to Frontiers in Pharmacogenetics and Pharmacogenomics, a specialty of Frontiers in Genetics.

Copyright (ㄷ 2012 Roco, Quiñones, Agúndez, García-Martín, Squicciarini, Miranda, Garay, Farfán, Saavedra, Cáceres, Ibarra and Varela. This is an open-access article distributed under the terms of the Creative Commons Attribution License, which permits use, distribution and reproduction in other forums, provided the original authors and source are credited and subject to any copyright notices concerning any third-party graphics etc. 